\title{
PENGARUH LAMA MELAUT DAN JUMLAH HAULING TERHADAP HASIL TANGKAPAN IKAN PADA PERIKANAN GILLNET SKALA KECIL DI PEKALONGAN JAWA TENGAH
}

\section{(EFFECS OF LENGTH TRIP AND TOTAL HAULING TO FISH CATCHES ON SMALL SCALE GILLNET FISHERIES IN PEKALONGAN, CENTRAL JAVA)}

\author{
${ }^{1}$ Eko Sri Wiyono \\ ${ }^{1}$ Corresponding author \\ Departemen Pemanfaatan Sumberdaya Perikanan \\ Fakultas Perikanan dan Ilmu Kelautan IPB \\ Jl. Lingkar Akademik Kampus IPB, Darmaga Bogor \\ E-mail: eko_ipb@yahoo.com
}

\begin{abstract}
The high competition among fishermen have resulted decreasing fish catches. To ensure the continuity of his activity, fishermen perform a variety of fishing strategies such as adding a length time of fishing trip at the sea and increasing the number of hauling. To assess the impact of both factors have been conducted research on gillnet small-scale fisheries $(<10 G T)$ in Pekalongan fishing port. Results of this study indicate that length of fishing trip have influence on both total and per species fish catches. Although length of fishing time more longer, result of this study showed that length of fishing trips do not affect to the fish price. On the other hand the results of this study indicate that the number or frequency of hauling apparently had no effect on either total catch or per species.
\end{abstract}

Keywords: Gillnet, length of fishing trip, hauling, Pekalongan

\begin{abstract}
ABSTRAK
Tingginya kompetisi antar nelayan mengakibatkan hasil tangkapan nelayan semakin menurun. Untuk menjamin kelangsungan kegiatan penangkapannya, nelayan melakukan berbagai macam strategi diantaranya adalah menambah lama trip penangkapan ikan di laut dan menambah jumlah hauling. Untuk mengkaji dampak kedua faktor tersebut telah dilakukan penelitian perikanan gillnet skala kecil $(<10 G T)$ di PPN Pekalongan. Hasil kajian ini menunjukkan bahwa lama trip penangkapan ikan sangat berpengaruh terhadap hasil tangkapan baik secara total maupun per species. Meskipun berlayar menangkap ikan lebih lama, ternyata berdasarkan penelitian ini tidak mempengaruhi harga ikan. Disisi yang lain hasil penelitian ini menunjukkan bahwa jumlah atau frekuensi hauling ternyata tidak berpengaruh terhadap hasil tangkapan baik secara total atau per species.
\end{abstract}

Kata kunci: Gillnet, hauling, lama trip penangkapan, Pekalongan

\section{PENDAhUluan}

Penangkapan ikan adalah kegiatan ekonomi yang berisiko tinggi. Untuk mengurangi risiko usaha, nelayan mengembangkan berbagai cara, baik mengembangkan teknologi penangkapan ikan yang digunakan untuk menangkap ikan maupun metode operasi penangkapannya. Berdasarkan jenis dan tingkah laku ikan, telah dikembangkan berbagai jenis alat tangkap ikan. Seiring dengan berkembangnya waktu, kebutuhan ikan semakin tinggi. Nelayan berusaha untuk mendapatkan ikan sebesarbesarnya yang berdampak terhadap menurunnya jumlah stok ikan. Sementara pada sisi yang lain, jumlah nelayan semakin banyak dan kompetisi antar mereka untuk mendapatkan ikan semakin tinggi. Dalam kondisi seperti ini, maka tingkat ketidakpastian untuk mendapatkan hasil tangkapan tinggi.

Sebagai langkah antisipasi untuk mempertahankan hasil tangkapannya, maka nelayan telah mengembangkan berbagai strategi. Disamping menciptakan alat tangkap baru atau memodifikasi alat tangkapnya, mereka juga telah melakukan berbagai cara atau metode dalam operasi penangkapannya. Upaya-upaya tersebut biasanya disesuaikan dengan berbagai 
macam faktor luar terutama iklim dan hasil tangkapan serta faktor internal utamanya modal dan sarana penangkapan ikannya (Salas, et al., 2004). Penguasaan mereka atas kondisi lingkungan (cuaca, gelombang dan arus), lokasi penangkapan ikan, keterampilan dalam pengoperasian alat tangkap serta alat bantu penangkapan ikan akan sangat membantu mereka dalam pengembangan berbagai macam strategi untuk mempertahankan kegiatan penangkapan ikannya. Namun demikian, secara umum mereka mewarisi pola-pola adaptasi dari orang tua mereka dalam menghadapi perubahan lingkungan yang ada di sekitarnya.

Gillnet adalah salah satu jenis alat tangkap yang populer dioperasikan oleh nelayan di Indonesia. Disamping sederhana dalam mengoperasikannya, alat tangkap ini juga tergolong relatif murah dibandingkan alat tangkap yang lainnya. Biasanya, gillnet dioperasikan di pantai dan daerah terumbu karang untuk menangkap baik jenis ikan pelagis atau demersal. Namun demikian, semakin bertambahnya nelayan maka produktivitas nelayan semakin menurun. Sebagai konsekuensinya, nelayan melakukan berbagai macam cara untuk mengoptimalkan hasil tangkapannya. Berbagai penelitian tentang gillnet sudah banyak dilakukan (Purbayanto, et al., 2000; Huse et al., 2000; and Reis, et al., 1999) di berbagai negara. Namun demikian, penelitian tentang metode operasi penangkapan ikan khususnya tentang pengaruh lama operasi dan banyaknya hauling penangapan ikan belum banyak dilakukan. Secara umum, nelayan akan melakukan penambahan input produksi atau memperpanjang waktu operasi penangkapan ikan untuk meningkatkan hasil tangkapannya. Namun belum diketahui apakah dampak dari penningkatan tersebut mampu meningkatkan hasil tangkapannya secara efektif dan efisien. Untuk itu maka penelitian tentang cara atau metode operasi penangkapan terhadap keefektifan operasi penangkapan ikan perlu dilakukan. Hal ini penting untuk dilakukan agar terhindar dari kecenderungan overcapacity (berlebihnya input produksi).
Penelitian ini dilaksanakan di Pekalongan, salah satu sentra perikanan di Indonesia. Dewasa ini, nelayan Pekalongan dalam upaya meningkatkan hasil tangkapannya telah melakukan strategi penangkapan ikan dengan cara memperpanjang hari operasi dan jumlah haulingnya. Untuk mengetahui dampak strategi itu, maka telah dilakukan suvei terhadap perahu-perahu gillnet yang mendaratkan hasil tangkapannya di PPN Pekalongan. Tujuan dari penelitian ini adalah 1) mengkaji pengaruh lama trip terhadap hasil tangkapan dan harga ikan serta 2) mengkaji pengaruh jumlah hauling terhadap hasil tangkapan dan harga ikan.

\section{METODOLOGI PENELITIAN}

Penelitian ini telah dilakukan di PPN (Pelabuhan Perikanan Nusantara) Pekalongan pada bulan Oktober 2012. Data diperoleh dari sensus pendataan produktivitas perahu gillnet yang melakukan pendaratan ikannnya di PPN Pekalongan. Pada penelitian ini difokuskan pada perahu gillnet yang berukuran dibawah 10 GT (<10 GT). Jenis data yang dikumpulkan meliputi jumlah trip dalam dua tahun terakhir (2011 - 2012), lama waktu melaut per trip, jumlah hauling dalam setiap trip dan hasil tangkapan (baik per jenis maupun total) setiap trip serta harga ikan (baik per jenis maupun total).

Untuk menjawab tujuan penelitian, maka data diolah dengan menggunakan ANOVA. Untuk memperoleh gambaran dari dampak perubahan lama trip penangkapan dan jumlah hauling terhadap hasil tangkapan maupun harga ikan hasil tangkapan, maka telah dilakukan analisis ANOVA. Untuk mengatahui dampak tersebut secara utuh, analisis telah dilakukan baik terhadap total hasil tangkapan maupun terhadap masingmasing species hasil tangkapan.

\section{HASIL DAN PEMBAHASAN}

\subsection{Hasil}

\subsubsection{Hasil Tangkapan}

Perahu gillnet yang berdomisili di PPN Pekalongan, umumnya melakukan penangkapan ikan di perairan pantai 
Laut Jawa. Perahu gillnet yang dioperasikan dari PPN Pekalongan mempunyai ukuran 5 sampai dengan 30 GT, tetapi dalam penelitian ini hanya difokuskan pada perikanan gillnet skala kecil yang mempunyai ukuran dibawah 10 GT. Kegiatan operasi penangkapan, membutuhkan waktu sekitar $2-27$ hari per trip tergantung keadaan di laut dan hasil tangkapan ikannya, tetapi secara umum satu trip penangkapan ikan membutuhkan waktu rata-rata sekitar 7 hari. Berdasarkan sensus terhadap perahu nelayan yang ada, maka berdasarkan pada Tabel 1 dapat diketahui bahwa ikan hasil tangkapan utama adalah ikan tongkol (64\%), sedangkan ikan tangkapan lainnya adalah ikan bukan tangkapan utama seperti manyung $(9,6 \%)$, cucut $(5,5 \%)$, layaran $(5,0 \%)$, lemang $(3,1 \%)$ dan beberapa ikan lainnya yang prosentasenya kecil (Tabel 1).

Bila ditinjau dari harga ikan hasil tangkapannya, dapat diketahui bahwa ikan hasil tangkapan utamanya yaitu tongkol bukan merupakan ikan yang memberikan harga tertinggi. Harga ikan tongkol masih lebih rendah dibandingkan dengan harga ikan tenggiri (Rp. 21.000/kg), kakap merah (Rp. 20.000,-/kg), bawal (Rp. 18.960,$/ \mathrm{kg}$ ), lemadang (Rp. 16.000,-/kg), manyung (Rp. 15.500,-/kg), lemang (Rp. $14.800,-/ \mathrm{kg})$ ), layaran (Rp. 12.500,-/kg), dan pari (Rp. 12.000,-/kg). Sementara dari jumlah total ikan hasil tangkapannya, maka dalam satu tahun kegiata penangkapan ikan dengan menggunakan gillnet <10GT ini akan menghasilkan penerimaan rata-rata sebesar Rp. 103.916.000,- per tahun (Tabel 1).

\subsubsection{Pengaruh lama trip terhadap total hasil tangkapan}

Sebagai upaya nelayan untuk meningkatkan hasil tangkapannya, adalah melakukan strategi penangkapan ikan dengan menambah waktu trip operasi penangkapan ikannya. Bila biasanya trip penangkapan ikan skala kecil dilakukan dalam waktu satu hari, maka sebagai strategi meningkatkan hasil tangkapannya adalah dengan cara memperpanjang waktu operasi penangkapan ikannya di laut. Panjang operasi penangkapan ikan nelayan Pekalongan dalam menghadapi rendahnya hasil tangkapan ini sangat bervariasi, mulai 2 hari per trip sampai dengan 27 hari per trip. Panjang pendeknya waktu operasi biasanya dibatasi oleh jumlah perbekalan dan sistem operasi penangkapan yang dijalankan oleh nelayan.

Hasil dari kajian ini menunjukkan bahwa lamanya trip penangkapan ikan sangat berpengaruh terhadap hasil tangkapan ikan. Uji ANOVA terhadap total hasil tangkapan ikan (t_tot) menunjukkan nilai signifikansi 0,003 (Tabel 2). Sementara

Tabel 1. Hasil tangkapan, jumlah penerimaan dan harga ikan hasil tangkapan gillnet < 10GT di PPN Pekalongan tahun 2011 - 2012

\begin{tabular}{lrrr}
\hline Jenis Ikan & $\begin{array}{l}\text { Hasil Tangkapan } \\
(\mathrm{kg})\end{array}$ & $\begin{array}{l}\text { Jumlah Penerimaan } \\
(\mathrm{Rp} / \text { tahun })\end{array}$ & $\begin{array}{l}\text { Harga Ikan } \\
(\mathrm{Rp} . / \mathrm{kg})\end{array}$ \\
\hline Tongkol & 5.553 & 62.745 .167 & 11.300 \\
Tenggiri & 257 & 5.398 .042 & 21.000 \\
Bawal & 33 & 616.208 & 18.960 \\
Cucut & 479 & 5.323 .750 & 11.100 \\
Manyung & 838 & 12.941 .375 & 15.500 \\
Kakap Merah & 120 & 2.400 .375 & 20.000 \\
Pari & 103 & 1.240 .958 & 12.000 \\
Layaran & 437 & 5.374 .000 & 12.300 \\
Campuran & 423 & 1.253 .792 & 3.000 \\
Lemang & 270 & 3.999 .167 & 14.800 \\
Lemadang & 163 & 2.623 .167 & 16.000 \\
\hline TOTAL & 8.676 & 103.916 .000 & \\
\hline
\end{tabular}


uji ANOVA untuk masing-masing species menunjukkan bahwa 7 species dari 11 species hasil tangkapan ikan gillnet menunjuukkan nilai sgnifikansi dibawah 0,05 (Tabel 2).

Disisi yang lain, hasil penelitian ini menunjukkan bahwa lamanya trip operasi penangkapan ikan tidak mempengaruhi jumlah hauling secara signifikan. Penambahan waktu operasi penangkapan ikan di laut, tidak berarti akan menambah jumlah hauling secara linear. Nelayan akan melakukan hauling penangkapan ikan hanya jika jumlah ikan yang ada di dalam gillnet telah mencapai jumlah yang memadai.

Tabel 2. Nilai signifikansi pengujian pengaruh lama waktu trip penangkapan ikan terhadap hasil tangkapan ikan dengan menggunakan ANOVA

\section{ANOVA}

\begin{tabular}{|c|c|c|c|c|c|c|}
\hline & & $\begin{array}{c}\text { Sum of } \\
\text { Squares }\end{array}$ & df & Mean Square & $\mathrm{F}$ & Sig. \\
\hline t_haul & $\begin{array}{l}\text { Between Groups } \\
\text { Within Groups } \\
\text { Total }\end{array}$ & $\begin{array}{l}102449,292 \\
325376,667 \\
427825,958 \\
\end{array}$ & $\begin{array}{l}9 \\
14 \\
23 \\
\end{array}$ & $\begin{array}{l}11383,255 \\
23241,190\end{array}$ & ,490 &, 858 \\
\hline t_tkl & $\begin{array}{l}\text { Between Groups } \\
\text { Within Groups } \\
\text { Total }\end{array}$ & $\begin{array}{l}9,082 \mathrm{E} 8 \\
5,029 \mathrm{E} 8 \\
1,411 \mathrm{E} 9 \\
\end{array}$ & $\begin{array}{l}9 \\
14 \\
23 \\
\end{array}$ & $\begin{array}{l}1,009 \mathrm{E} 8 \\
3,592 \mathrm{E} 7\end{array}$ & 2,809 &, 041 \\
\hline t_tgr & $\begin{array}{l}\text { Between Groups } \\
\text { Within Groups } \\
\text { Total }\end{array}$ & $\begin{array}{l}2321472,705 \\
472232,629 \\
2793705,333 \\
\end{array}$ & $\begin{array}{l}9 \\
14 \\
23 \\
\end{array}$ & $\begin{array}{l}257941,412 \\
33730,902\end{array}$ & 7,647 & ,000 \\
\hline t_bwl & $\begin{array}{l}\text { Between Groups } \\
\text { Within Groups } \\
\text { Total }\end{array}$ & $\begin{array}{l}50992,200 \\
24245,800 \\
75238,000 \\
\end{array}$ & $\begin{array}{l}9 \\
14 \\
23 \\
\end{array}$ & $\begin{array}{l}5665,800 \\
1731,843\end{array}$ & 3,272 &, 023 \\
\hline t_cct & $\begin{array}{l}\text { Between Groups } \\
\text { Within Groups } \\
\text { Total }\end{array}$ & $\begin{array}{l}4821694,325 \\
6288987,300 \\
1,111 \mathrm{E} 7\end{array}$ & $\begin{array}{l}9 \\
14 \\
23\end{array}$ & $\begin{array}{l}535743,814 \\
449213,379\end{array}$ & 1,193 &, 370 \\
\hline t_mng & $\begin{array}{l}\text { Between Groups } \\
\text { Within Groups } \\
\text { Total }\end{array}$ & $\begin{array}{l}2,362 \mathrm{E} 7 \\
1,058 \mathrm{E} 7 \\
3,420 \mathrm{E} 7 \\
\end{array}$ & $\begin{array}{l}9 \\
14 \\
23 \\
\end{array}$ & $\begin{array}{l}2624201,949 \\
755676,700\end{array}$ & 3,473 & ,018 \\
\hline t_kmr & $\begin{array}{l}\text { Between Groups } \\
\text { Within Groups } \\
\text { Total }\end{array}$ & $\begin{array}{l}682379,843 \\
770448,157 \\
1452828,000 \\
\end{array}$ & $\begin{array}{l}9 \\
14 \\
23 \\
\end{array}$ & $\begin{array}{l}75819,983 \\
55032,011\end{array}$ & 1,378 & ,285 \\
\hline t_par & $\begin{array}{l}\text { Between Groups } \\
\text { Within Groups } \\
\text { Total }\end{array}$ & $\begin{array}{l}346737,044 \\
223519,914 \\
570256,958 \\
\end{array}$ & $\begin{array}{l}9 \\
14 \\
23 \\
\end{array}$ & $\begin{array}{l}38526,338 \\
15965,708\end{array}$ & 2,413 & ,068 \\
\hline t_lyr & $\begin{array}{l}\text { Between Groups } \\
\text { Within Groups } \\
\text { Total }\end{array}$ & $\begin{array}{l}2,905 \mathrm{E} 7 \\
543347,395 \\
2,959 \mathrm{E} 7 \\
\end{array}$ & $\begin{array}{l}9 \\
14 \\
23 \\
\end{array}$ & $\begin{array}{l}3227331,160 \\
38810,528\end{array}$ & 83,156 &, 000 \\
\hline t_cpr & $\begin{array}{l}\text { Between Groups } \\
\text { Within Groups } \\
\text { Total }\end{array}$ & $\begin{array}{l}1,206 \mathrm{E} 7 \\
1157499,714 \\
1,322 \mathrm{E} 7 \\
\end{array}$ & $\begin{array}{l}9 \\
14 \\
23 \\
\end{array}$ & $\begin{array}{l}1340386,013 \\
82678,551\end{array}$ & 16,212 & ,000 \\
\hline t_rmg & $\begin{array}{l}\text { Between Groups } \\
\text { Within Groups } \\
\text { Total }\end{array}$ & $\begin{array}{l}3098387,105 \\
3162084,729 \\
6260471,833 \\
\end{array}$ & $\begin{array}{l}9 \\
14 \\
23 \\
\end{array}$ & $\begin{array}{l}344265,234 \\
225863,195\end{array}$ & 1,524 &, 231 \\
\hline t_lmg & $\begin{array}{l}\text { Between Groups } \\
\text { Within Groups } \\
\text { Total }\end{array}$ & $\begin{array}{l}1911884,319 \\
248317,514 \\
2160201,833 \\
\end{array}$ & $\begin{array}{l}9 \\
14 \\
23 \\
\end{array}$ & $\begin{array}{l}212431,591 \\
17736,965\end{array}$ & 11,977 & ,000 \\
\hline t_tot & $\begin{array}{l}\text { Between Groups } \\
\text { Within Groups } \\
\text { Total }\end{array}$ & $\begin{array}{l}2,082 \mathrm{E} 9 \\
6,202 \mathrm{E} 8 \\
2,702 \mathrm{E} 9 \\
\end{array}$ & $\begin{array}{l}9 \\
14 \\
23\end{array}$ & $\begin{array}{l}2,313 \mathrm{E} 8 \\
4,430 \mathrm{E} 7\end{array}$ & 5,222 & ,003 \\
\hline
\end{tabular}




\subsubsection{Pengaruh lama trip terhadap harga ikan hasil tangkapan}

Ikan merupakan produk yang sangat mudah rusak, berdasarkan tekstur dan kesegarannya akan menentukan harga ikan tersebut. Semakin lama ikan tertangkap, bila tidak dilakukan penanganan yang memadai akan menyebabkan kerusakan ikan. Untuk itu dalam kajian ini telah diuji seberapa besar pengaruh lamanya operasi penangkapan ikan terhadap harga ikan yang dijual nelayan di PPN Pekalongan. Hasil kajian ini menunjukkan bahwa secara umum, lama operasi penangkapan ikan tidak mempengaruhi harga ikan hasil tangkapan, baik total maupun ikan per species (Tabel 3).

Tabel 3. Nilai signifikansi pengujian pengaruh lama waktu trip penangkapan ikan terhadap harga ikan hasil tangkapan dengan menggunakan ANOVA

\begin{tabular}{|c|c|c|c|c|c|c|}
\hline & & $\begin{array}{l}\text { Sum of } \\
\text { Squares }\end{array}$ & df & Mean Square & $\mathrm{F}$ & Sig. \\
\hline jml_haul & $\begin{array}{l}\text { Between Groups } \\
\text { Within Groups } \\
\text { Total }\end{array}$ & $\begin{array}{l}89492,038 \\
79525,295 \\
169017,333\end{array}$ & $\begin{array}{l}9 \\
14 \\
23\end{array}$ & $\begin{array}{l}9943,560 \\
5680,378\end{array}$ & 1,751 &, 168 \\
\hline h_tkl & $\begin{array}{l}\text { Between Groups } \\
\text { Within Groups } \\
\text { Total }\end{array}$ & $\begin{array}{l}2,034 \mathrm{E} 7 \\
2,013 \mathrm{E} 8 \\
2,217 \mathrm{E} 8\end{array}$ & $\begin{array}{l}9 \\
14 \\
23\end{array}$ & $\begin{array}{l}2259714,535 \\
1,438 \mathrm{E} 7\end{array}$ &, 157 & ,996 \\
\hline h_tgr & $\begin{array}{l}\text { Between Groups } \\
\text { Within Groups } \\
\text { Total }\end{array}$ & $\begin{array}{l}8,999 \mathrm{E} 8 \\
1,301 \mathrm{E9} \\
2,200 \mathrm{E} 9\end{array}$ & $\begin{array}{l}9 \\
14 \\
23\end{array}$ & $\begin{array}{l}9,999 \mathrm{E} 7 \\
9,290 \mathrm{E} 7\end{array}$ & 1,076 &, 435 \\
\hline h_bwl & $\begin{array}{l}\text { Between Groups } \\
\text { Within Groups } \\
\text { Total }\end{array}$ & $\begin{array}{l}1,124 \mathrm{E} 9 \\
1,052 \mathrm{E9} \\
2,176 \mathrm{E9}\end{array}$ & $\begin{array}{l}9 \\
14 \\
23\end{array}$ & $\begin{array}{l}1,249 \mathrm{E} 8 \\
7,511 \mathrm{E} 7\end{array}$ & 1,663 &, 190 \\
\hline h_ttc & $\begin{array}{l}\text { Between Groups } \\
\text { Within Groups } \\
\text { Total }\end{array}$ & $\begin{array}{l}4,509 \mathrm{E} 8 \\
8,858 \mathrm{E} 8 \\
1,337 \mathrm{E} 9\end{array}$ & $\begin{array}{l}9 \\
14 \\
23\end{array}$ & $\begin{array}{l}5,010 \mathrm{E} 7 \\
6,327 \mathrm{E} 7\end{array}$ & ,792 & ,629 \\
\hline h_mng & $\begin{array}{l}\text { Between Groups } \\
\text { Within Groups } \\
\text { Total }\end{array}$ & $\begin{array}{l}5,698 \mathrm{E} 8 \\
6,426 \mathrm{E} 8 \\
1,212 \mathrm{E} 9 \\
\end{array}$ & $\begin{array}{l}9 \\
14 \\
23 \\
\end{array}$ & $\begin{array}{l}6,331 \mathrm{E} 7 \\
4,590 \mathrm{E} 7\end{array}$ & 1,379 & 284 \\
\hline h_kmr & $\begin{array}{l}\text { Between Groups } \\
\text { Within Groups } \\
\text { Total }\end{array}$ & $\begin{array}{l}1,312 \mathrm{E9} \\
1,811 \mathrm{E9} \\
3,123 \mathrm{E} 9\end{array}$ & $\begin{array}{l}9 \\
14 \\
23\end{array}$ & $\begin{array}{l}1,458 \mathrm{E} 8 \\
1,294 \mathrm{E} 8\end{array}$ & 1,127 & ,406 \\
\hline h_par & $\begin{array}{l}\text { Between Groups } \\
\text { Within Groups } \\
\text { Total }\end{array}$ & $\begin{array}{l}4,393 \mathrm{E} 8 \\
3,741 \mathrm{E} 8 \\
8,134 \mathrm{E} 8 \\
\end{array}$ & $\begin{array}{l}9 \\
14 \\
23 \\
\end{array}$ & $\begin{array}{l}4,882 \mathrm{E} 7 \\
2,672 \mathrm{E} 7\end{array}$ & 1,827 &, 151 \\
\hline h_lyr & $\begin{array}{l}\text { Between Groups } \\
\text { Within Groups } \\
\text { Total }\end{array}$ & $\begin{array}{l}192,935 \\
536,024 \\
728,958\end{array}$ & $\begin{array}{l}9 \\
14 \\
23\end{array}$ & $\begin{array}{l}21,437 \\
38,287\end{array}$ &, 560 & ,808 \\
\hline h_cpr & $\begin{array}{l}\text { Between Groups } \\
\text { Within Groups } \\
\text { Total }\end{array}$ & $\begin{array}{l}64,830 \\
55,129 \\
119,958 \\
\end{array}$ & $\begin{array}{l}9 \\
14 \\
23\end{array}$ & $\begin{array}{l}7,203 \\
3,938\end{array}$ & 1,829 &, 150 \\
\hline h_rmg & $\begin{array}{l}\text { Between Groups } \\
\text { Within Groups } \\
\text { Total }\end{array}$ & $\begin{array}{l}795,276 \\
852,557 \\
1647,833 \\
\end{array}$ & $\begin{array}{l}9 \\
14 \\
23 \\
\end{array}$ & $\begin{array}{l}88,364 \\
60,897\end{array}$ & 1,451 & 257 \\
\hline h_lmg & $\begin{array}{l}\text { Between Groups } \\
\text { Within Groups } \\
\text { Total }\end{array}$ & $\begin{array}{l}684,758 \\
443,200 \\
1127,958 \\
\end{array}$ & $\begin{array}{l}9 \\
14 \\
23 \\
\end{array}$ & $\begin{array}{l}76,084 \\
31,657\end{array}$ & 2,403 & ,069 \\
\hline h_tot & $\begin{array}{l}\text { Between Groups } \\
\text { Within Groups } \\
\text { Total }\end{array}$ & $\begin{array}{l}16,505 \\
51,959 \\
68,464\end{array}$ & $\begin{array}{l}9 \\
14 \\
23\end{array}$ & $\begin{array}{l}1,834 \\
3,711\end{array}$ & ,494 & ,855 \\
\hline
\end{tabular}




\subsubsection{Pengaruh jumlah hauling terhadap total hasil tangkapan}

Strategi lain yang dilakukan oleh nelayan untuk memperbanyak hasil tangkapan adalah meningkatkan frekuensi pengangkatan jaring (hauling). Dalam kajian ini telah dilakukan pengujian terhadap frekuansi hauling terhadap hasil tangkapan ikan. Hasil kajian ini menunjukkan bahwa frekuensi atau jumlah hauling tidak memberikan dampak signifikan terhadap hasil tangkapan baik terhadap total hasil tangkapan ataupun hasil tangkapan per spesies (Tabel 4).

\subsection{Pembahasan}

Perikanan skala kecil merupakan basis penggerak roda ekonomi yang penting bagi masyarakat kawasan pesisir dalam hal sumber mata pencaharian dan memberi pendapatan secara langsung khususnya bagi para nelayan. Hampir 90\% kegiatan perikanan di Dunia umumnya (FAO, 2012) dan di Indonesia khususnya didominasi oleh perikanan skala kecil.

Tabel 4. Nilai signifikansi pengujian pengaruh jumlah hauling terhadap hasil tangkapan ikan dengan menggunakan ANOVA

\begin{tabular}{|c|c|c|c|c|c|c|}
\hline & & $\begin{array}{c}\text { Sum of } \\
\text { Squares }\end{array}$ & $\mathrm{df}$ & Mean Square & $\mathrm{F}$ & Sig. \\
\hline t_tkl & $\begin{array}{l}\text { Between Groups } \\
\text { Within Groups } \\
\text { Total }\end{array}$ & $\begin{array}{l}1,306 \mathrm{E} 9 \\
1,049 \mathrm{E} 8 \\
1,411 \mathrm{E} 9 \\
\end{array}$ & $\begin{array}{l}22 \\
1 \\
23 \\
\end{array}$ & $\begin{array}{l}5,937 \mathrm{E} 7 \\
1,049 \mathrm{E} 8\end{array}$ &, 566 & ,803 \\
\hline t_tgr & $\begin{array}{l}\text { Between Groups } \\
\text { Within Groups } \\
\text { Total }\end{array}$ & $\begin{array}{l}2353783,333 \\
439922,000 \\
2793705,333 \\
\end{array}$ & $\begin{array}{l}22 \\
1 \\
23 \\
\end{array}$ & $\begin{array}{l}106990,152 \\
439922,000\end{array}$ & ,243 & ,945 \\
\hline t_bwl & $\begin{array}{l}\text { Between Groups } \\
\text { Within Groups } \\
\text { Total }\end{array}$ & $\begin{array}{l}74438,000 \\
800,000 \\
75238,000\end{array}$ & $\begin{array}{l}22 \\
1 \\
23 \\
\end{array}$ & $\begin{array}{l}3383,545 \\
800,000\end{array}$ & 4,229 & ,368 \\
\hline t_cct & $\begin{array}{l}\text { Between Groups } \\
\text { Within Groups } \\
\text { Total }\end{array}$ & $\begin{array}{l}9778969,625 \\
1331712,000 \\
1,111 \mathrm{E} 7 \\
\end{array}$ & $\begin{array}{l}22 \\
1 \\
23 \\
\end{array}$ & $\begin{array}{l}444498,619 \\
1331712,000\end{array}$ & ,334 & ,903 \\
\hline t_mng & $\begin{array}{l}\text { Between Groups } \\
\text { Within Groups } \\
\text { Total }\end{array}$ & $\begin{array}{l}2,395 \mathrm{E} 7 \\
1,024 \mathrm{E} 7 \\
3,420 \mathrm{E} 7 \\
\end{array}$ & $\begin{array}{l}22 \\
1 \\
23 \\
\end{array}$ & $\begin{array}{l}1088861,515 \\
1,024 \mathrm{E} 7\end{array}$ &, 106 & ,994 \\
\hline t_kmr & $\begin{array}{l}\text { Between Groups } \\
\text { Within Groups } \\
\text { Total }\end{array}$ & $\begin{array}{l}1341436,000 \\
111392,000 \\
1452828,000 \\
\end{array}$ & $\begin{array}{l}22 \\
1 \\
23 \\
\end{array}$ & $\begin{array}{l}60974,364 \\
111392,000\end{array}$ &, 547 &, 810 \\
\hline t_par & $\begin{array}{l}\text { Between Groups } \\
\text { Within Groups } \\
\text { Total }\end{array}$ & $\begin{array}{l}532992,458 \\
37264,500 \\
570256,958 \\
\end{array}$ & $\begin{array}{l}22 \\
1 \\
23 \\
\end{array}$ & $\begin{array}{l}24226,930 \\
37264,500\end{array}$ &, 650 &, 772 \\
\hline t_lyr & $\begin{array}{l}\text { Between Groups } \\
\text { Within Groups } \\
\text { Total }\end{array}$ & $\begin{array}{l}1,865 \mathrm{E} 7 \\
1,094 \mathrm{E} 7 \\
2,959 \mathrm{E} 7 \\
\end{array}$ & $\begin{array}{l}22 \\
1 \\
23 \\
\end{array}$ & $\begin{array}{l}847612,992 \\
1,094 \mathrm{E} 7\end{array}$ &, 077 & ,998 \\
\hline t_cpr & $\begin{array}{l}\text { Between Groups } \\
\text { Within Groups } \\
\text { Total }\end{array}$ & $\begin{array}{l}1,318 \mathrm{E} 7 \\
36450,000 \\
1,322 \mathrm{E} 7 \\
\end{array}$ & $\begin{array}{l}22 \\
1 \\
23 \\
\end{array}$ & $\begin{array}{l}599296,538 \\
36450,000\end{array}$ & 16,442 &, 193 \\
\hline t_rmg & $\begin{array}{l}\text { Between Groups } \\
\text { Within Groups } \\
\text { Total }\end{array}$ & $\begin{array}{l}6002709,833 \\
257762,000 \\
6260471,833 \\
\end{array}$ & $\begin{array}{l}22 \\
1 \\
23 \\
\end{array}$ & $\begin{array}{l}272850,447 \\
257762,000\end{array}$ & 1,059 & ,658 \\
\hline t_lmg & $\begin{array}{l}\text { Between Groups } \\
\text { Within Groups } \\
\text { Total }\end{array}$ & $\begin{array}{l}2116983,833 \\
43218,000 \\
2160201,833 \\
\end{array}$ & $\begin{array}{l}22 \\
1 \\
23 \\
\end{array}$ & $\begin{array}{l}96226,538 \\
43218,000\end{array}$ & 2,227 &, 490 \\
\hline t_tot & $\begin{array}{l}\text { Between Groups } \\
\text { Within Groups } \\
\text { Total }\end{array}$ & $\begin{array}{l}2,522 \mathrm{E} 9 \\
1,799 \mathrm{E} 8 \\
2,702 \mathrm{E} 9 \\
\end{array}$ & $\begin{array}{l}22 \\
1 \\
23\end{array}$ & $\begin{array}{l}1,146 \mathrm{E} 8 \\
1,799 \mathrm{E} 8\end{array}$ &, 637 &, 777 \\
\hline
\end{tabular}


Nelayan skala kecil dicirikan dengan berbagai keterbatasan diantaranya adalah keterbatasan waktu melaut yang disebabkan oleh faktor kondisi cuaca yang tidak bersahabat atau jenis kapal atau alat tangkap yang digunakan oleh para nelayan (Salas et al., 2004). Perkembangan perikanan skala kecil yang sedemikian pesat mengakibatkan kompetisi diantara mereka sangat tinggi. Sebagai akibatnya, sumberdaya ikan terkuras habis dan pendapatan mereka semakin menurun. Wiyono et al., (2006) menyatakan bahwa aktivitas yang dilakukan pada perikanan skala kecil, pada batas-batas tertentu mempunyai korelasi/berpengaruh pada reduksi biomassa, kelimpahan sumberdaya ikan, ataupun ukuran individu dari target ikan. Sebagai langkah antisipasi atas persoalan yang ada, nelayan mengembangkan berbagai strategi/ taktik operasi penangkapan ikan (Andersen \& Christensen, 2006; Cinner et al., 2008) salah satunya adalah memperpanjang waktu operasi penangkapan ikan. Perpanjangan waktu operasi penangkapan ikan dapat diartikan pula bahwa proses menangkap ikan yang biasa mereka lakukan sudah tidak menghasilkan hasil tangkapan seperti sebelumnya, sehingga mereka harus menambah upaya penangkapan ikan dengan memperpanjang trip penangkapan ikan. Kondisi ini juga merupakan pertanda bahwa ikan sudah mulai sedikit sehingga diperlukan upaya yang lebih. Strategi/taktik memperpanjang waktu operasi penangkapan ikan juga telah dilakukan oleh nelayan skala kecil di Pekalongan. Mereka melakukan respon perpanjangan trip penangkapan ikan dengan cara yang berbeda-beda. Hal ini sesuai dengan pendapat Salas et al. (2004), Bene \& Tewfik (2001), Salas \& Charles (2007), dan Daw et al., (2011) yang menyatakan bahwa setiap individu mempunyai kecenderungan respon yang berbedabeda tergantung pemahaman mereka terhadap cuaca, pasar, sumberdaya ikan, kapal/alat tangkap dan keterampilan yang dimiliki. Hasil dari penelitian ini menunjukkan bahwa perpanjangan waktu trip operasi penangkapan ikan pada perikanan gillnet skala kecil di Pekalongan berpengaruh terhadap hasil tangkapan mereka. Namun demikian, penambahan lama trip operasi penangkapan ikan bukan berarti menambah jumlah atau frekuensi hauling. Mereka diduga telah melakukan operasi penangkapan ikan dengan cara yang efektif dan efisien. Meraka hanya akan melakukan hauling ketika benar-benar akan mendapatkan ikan yang memadai. Penghematan hauling, berarti penghematan biaya operasi penangkapan yang menjadi kendala mereka saat ini. Dengan bekal operasi penangkapan yang terbatas mereka akan melakukan hauling pada saat yang tepat saja. Disisi lain, hasil penelitian ini juga menunjukkan bahwa lamanya operasi penangkapan ikan tidak berdampak terhadap kualitas ikan yang mereka daratkan, terbukti lama operasi penangkapan ikan tidak berdampak terhadap harga ikan. Nelayan diduga telah menerapkan sistem pasca panen yang lebih baik, sehingga ikan tetap segar.

\section{KESIMPULAN DAN SARAN}

\subsection{Kesimpulan}

Nelayan mengembangkan strategi operasi penangkapan ikannya sesuai dengan kapasitas yang mereka miliki. Sehubungan dengan keterbatasan modal usaha dan investasi, mereka melakukan strategi memperpanjang lama trip penangkapan ikan. Berdasarkan dari penelitian ini dapat disimpulkan bahwa:

1) Lama trip operasi penangkapan ikan berpengaruh terhadap hasil tangkapan. Lama trip operasi penangkapan ikan berpengaruh terhadap total hasil tangkapan dan mayoritas ikan per species.

2) Banyaknya hauling tidak berpengaruh terhadap hasil tangkapan ikan, baik total maupun per species ikan

\subsection{Saran}

Agar kegiatan penangkapan ikan terkontrol dan manejemen perikanan menyentuh akar masalah yang dihadapi oleh nelayan, sudah saatnya jika manajemen perikanan tidak didasarkan pada aspek teknis dan biologi semata tetapi juga memberikan perhatian yang 
lebih terhadap aspek sosial-ekologi, yaitu bagaimana nelayan melakukan respon terhadap perubahan yang ada di sekitarnya. Penambahan lama trip penangkapan ikan, pada dasarnya adalah penambahan upaya penangkapan ikan, sehingga perubahan ini juga perlu diperhitungkan dalam pengkajian jumlah upaya penangkapan ikan sesungguhnya.

\section{DAFTAR PUSTAKA}

Andersen, B. S., and Christensen, A.S. 2006. Modelling shor-term choice behaviour of Danish Fishermen in a mixed fishery. In $U$. R. Sumaila, \& A. D. Marsden (Ed.), 2005 North American Association Fisheries Economist Forum Proceedings. 14(1), pp. 13-26. Vancouver, Canada: Fisheries Centre, the University of British Columbia.

Bene, C., and Tewfik, A. June 2001. Fishing Effort Allocation and Fishermen's Decision Making Process in a Multi-Species SmallScale Fishery: Analysis of the Conch and Lobster Fishery in Turks and Caicos Islands. Human Ecology. No.29 (2): 157186.

Cinner, J., Daw, T., and McClanahan, T. 2008. Socioeconomic factors that affect artisanal fishers' readiness to exit a declining fishery. Conservation Biology. No 23 (1): 124-130.

Daw, T., Maina, J., Cinner, J., Robinson, J., and Wamukota, A. December 2011. The Spatial behaviour of artisanal fishers: Implications for fisheries management and development (Fishers in space). School of Development Studies University of East Anglia. UK: Western Indian Ocean Marine Science

Association (WIOMSCA).
FAO. 2012. The State of World Fisheries and Aquaculture 2012. Rome: FAO.

Huse I., Løkkeborg, S and Aud Soldal V. 2000. Relative selectivity in trawl, longline and gillnet fisheries for cod and haddock. ICES Journal of Marine Science, 57: 12711282.

Purbayanto, A, Akiyama, S, Tokai, T, and Arimoto, T. 2000. Mesh selectivity of a sweeping trammel net for Japanese whiting Sillago japonica. Fisheries Science. Volume 66, Issue 1, pages 97103.

Reis, E.G., and Pawson M.G. 1999. Fish morphology and estimating selectivity by gillnets fishery in Victoria, Australia. Fishery Research Vol. 39: 263-273.

Salas, S., and Charles, A. November 5 9. 2007. Are small-scale fishers profit maximizers?: Exploring fishing performance of smallscale fishers and factors determining catch rates. Proceedings of the 60th Gulf and Caribbean Fisheries Institute. pp. 117-124. Punta Cana: GCFI.

Salas, S., and Gaertner, D. 2004. The Behavioural Dynamics of Fishers: Management Implications. Fish and Fisheries. No. 5: 153 - 167.

Wiyono, E. S., Yamada, S., Tanaka, E., and Kitakado, T. (2006). Fishing strategy for target spesies of small-scale fisheries in Pelabuhanratu Bay, Indonesia. La Mer. No. 44: 85-93. 